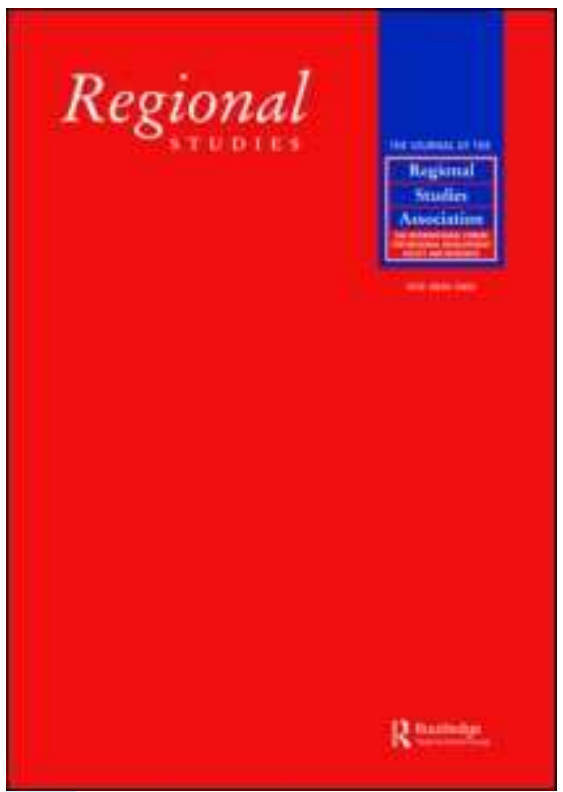

\title{
RDA POLICY TO TACKLE ECONOMIC EXCLUSION? THE ROLE OF SOCIAL CAPITAL IN DISTRESSED COMMUNITIES
}

\begin{tabular}{|r|l|}
\hline Journal: & Regional Studies \\
\hline Manuscript ID: & CRES-2005-0156.R1 \\
\hline Manuscript Type: & Policy Debates \\
\hline JEL codes: & $\begin{array}{l}\text { O10 - General < O1 - Economic Development < O - Economic } \\
\text { Development, Technological Change, and Growth, O17 - Formal, } \\
\text { Informal Sectors; Shadow Economy, etc. < O1 - Economic } \\
\text { and Growth, R58 - Regional Development Policy < R5 - Regional } \\
\text { Government Analysis < R - Urban, Rural, and Regional Economics }\end{array}$ \\
\hline Keywords: & $\begin{array}{l}\text { Social Capital, economic exclusion, community economic } \\
\text { development, regional policy, Regional Development Agency (RDA) }\end{array}$ \\
\hline
\end{tabular}

\section{SCHOLARONE Manuscripts}




\section{RDA POLICY TO TACKLE ECONOMIC EXCLUSION? \\ THE ROLE OF SOCIAL CAPITAL IN DISTRESSED \\ COMMUNITIES $^{1}$}

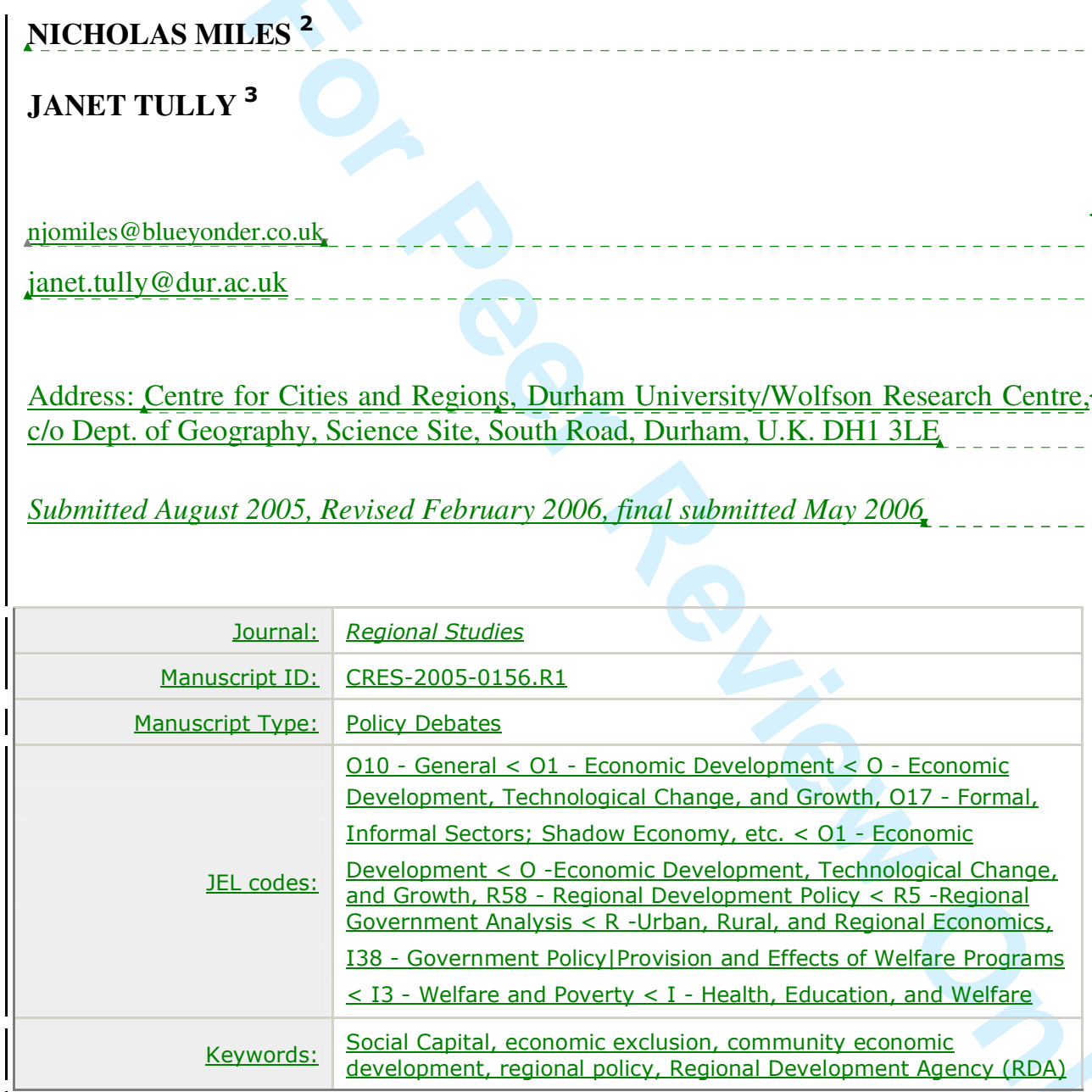

Formatted: Font: $12 \mathrm{pt}$, Complex Script Font: 12 pt

\begin{tabular}{|c|}
\hline $\begin{array}{l}\text { Formatted: Body Text, Space After: } \\
0 \text { pt, Line spacing: single }\end{array}$ \\
\hline \\
\hline Field Code Changed \\
\hline $\begin{array}{l}\text { Formatted: Font: } 10.5 \mathrm{pt} \text {, Complex } \\
\text { Script Font: } 10 \mathrm{pt}\end{array}$ \\
\hline Formatted: Font: Not Italic \\
\hline $\begin{array}{l}\text { Formatted: Char, Font: Not Italic, } \\
\text { Complex Script Font: } 10 \text { pt, Italic }\end{array}$ \\
\hline $\begin{array}{l}\text { Formatted: Char, Font: Not Italic, } \\
\text { Complex Script Font: } 10 \text { pt, Italic }\end{array}$ \\
\hline Formatted: Font: Not Italic \\
\hline Formatted: Line spacing: single \\
\hline $\begin{array}{l}\text { Deleted: August 2005, Revised } \\
\text { February } 2006\end{array}$ \\
\hline
\end{tabular}

Submitted August 2005, Revised February 2006, final submitted May 2006 


\section{ABSTRACT}

Economic exclusion and 'worklessness' are high on the current political agenda; both continue to characterise large areas of the North East of England, as clearly indicated by UK regional statistics on multiple deprivation. Understandably, a key priority of the Regional Development Agency for the North East (One NorthEast, ONE) is the economic (inclusive) development of the region.

Social capital is increasingly seen by policy makers as an important pathway to increased economic inclusion for distressed communities (GROOTAERT. 1998; PUTNAM 2000; CASEY 2004). By helping individuals and groups develop confidence, social networks, and trust and behaviour norms, it has been argued that increased social capital can enhance the employability of individuals, and the employment capacities and capabilities of the communities in which those individuals are embedded.

In this study an assessment was made as to whether the social capital of individuals in distressed communities could be enhanced by local community development programmes - which are increasingly seen as alternative mechanism for improving economic inclusion - and, subsequently, whether the employability and employment opportunities of programme participants increased. Based on this assessment, several policy recommendations were made to the regional development agency.

Introduction
Formatted: Font: $12 \mathrm{pt}$, Complex Script Font: $12 \mathrm{pt}$

Formatted: Font: $12 \mathrm{pt}$, Not Italic Complex Script Font: 12 pt

Formatted: Font: $12 \mathrm{pt}$, Complex Script Font: $12 \mathrm{pt}$

Formatted: Font: $12 \mathrm{pt}$, Not Italic, Complex Script Font: $12 \mathrm{pt}$

Deleted: in

Deleted: increased economic inclusion

Formatted: Font: Not Italic

Formatted: Font: 12 pt, Complex Script Font: 12 pt

Deleted: Key words: social capital; economic exclusion; community economic development; policy; Regional Development Agency (RDA)प 
Economic exclusion and 'worklessness' is high on the current political agenda. As demonstrated by OXLEY (1999) the vast majority of the 'continuously poor' in the UK live in workless households, namely households which contain those who are of working age but are unemployed or economically inactive, and, therefore, deemed to be economically excluded ${ }^{4}$. In 2001 the Labour Force Survey classified 17 percent of households in the North East of England as 'workless' ${ }^{5}$ compared to a UK average of just over 11 percent. Furthermore, economic exclusion costs the public purse dearly. In 2003 , out of a total public sector expenditure of some $£ 13.2$ billion pounds in the North East, around £5.4 billion, namely 41 per cent, was spent on unemployment and incapacity benefit ${ }^{6}$.

During the past decade a myriad of national and locally based policies, programmes and projects have been devised in order to address the issues of economic exclusion and worklessness (see HUDSON 1989, 2005). Economic exclusion, however, continues to characterise large areas of the North East, as clearly indicated by UK regional statistics on multiple deprivation. It is, therefore, understandable that a key priority of the Regional Development Agency (RDA) for the North East (One NorthEast, ONE) is the promotion of employment and economic inclusion for those deemed to be disadvantaged.

In response to persistent laggardness, and in common with a number of other regional economic development agencies, ONE has experimented with a more 'holistic' approach to regional economic development. This approach involves combining and integrating actions addressing housing, health, education, and cultural issues, with more traditional area-based regeneration interventions such as physical infrastructure interventions or support for intermediate labour markets and small businesses. 
Community or local development programmes are increasingly regarded by academics and regeneration practitioners as one of the more appropriate delivery mechanisms for this more holistic approach (see ERRO 1997).

Parallel to this shift of interest has been the growing awareness of the concept of social capital. Social capital has come to be regarded as an increasingly important 'holistic' policy instrument which can be used to promote economic inclusion. Investing in and building social capital is now seen as providing an important pathway to economic prosperity, by institutions such as the World Bank (GROOTAERT 1998). This is to be achieved by helping individuals and groups develop social networks, trust and behavioural norms, which, inter alia, will improve their own employability, increase opportunities to access employment and, enhance community capacities and capabilities.

This aim of the paper is to propose social capital policy responses for regional economic development based on the synthesis of the findings of a concentrated study and the literature debate. It first presents a brief review of the concept of social capital and its use as policy tool. Secondly, it highlights results of an investigation as to whether community development projects ${ }^{7}$ in the North East of England build social capital and are subsequently improving the employability and the economic inclusion of those that are workless. Thirdly, the paper suggests policy recommendations; which encourage the building of social capital in the North East. It concludes with the suggestion that the promotion of social capital can be a significant 'policy' response for persistently laggard, distressed regions in the UK, such as the North East, especially when joined up with more orthodox forms of policy.
Formatted: Font: $12 \mathrm{pt}$, Not Italic, Complex Script Font: 12 pt

Formatted: Font: $12 \mathrm{pt}$, Complex Script Font: $12 \mathrm{pt}$
Deleted:

Deleted: , especially

Formatted: Font: $12 \mathrm{pt}$, Complex Script Font: $12 \mathrm{pt}$ 


\section{The Concept and Use of Social Capital}

Social capital is, prima facie, a simple concept. It is based on the premise that who you know is as important as what you know. It acknowledges that personal relationships and social networks matter. The shared values and empathy generated between people when they interact facilitates co-operation and develops trust between individuals and groups, which is arguably the foundation of all civic society and socio-economic wellbeing.

Hence, we define the concept of social capital as the personal contacts and social networks that generate shared understandings, trust and reciprocity within and between social groups, and which can facilitate co-operation and collective action, a basis for economic prosperity and economic inclusion. Social capital can be built or accumulated when people interact in a purposeful manner with each other in families, workplaces, neighbourhoods, local associations and a range of informal and formal meeting places. Social capital is often seen as the social glue that holds together an economy (and increasingly is seen as a key component of endogenous growth theories). In a national economy an absence of social capital is often seen as a feature of market failure, in which co-operation, collective action, risk sharing, innovation and entrepreneurship are lacking or severely constrained. This form of market failure can also characterise regional economies and disadvantaged local communities.

The concept of social capital is frequently seen as a panacea for the ills of social and economic exclusion, and deprivation. Indeed, social capital has been promoted as the 'missing link' in development (GROOTAERT 1998), and as a way of rebuilding the social and economic foundations of distressed communities by promoting horizontal 
forms of association and mutual support amongst such communities, and by linking the disadvantaged and excluded in vertical forms of association with those in power. WOOLCOCK (2001) argues that social capital can allow a community to recover from an external shock, e.g., by enabling the members of a locality suffering from the closure of a large manufacturing plant to access resources and support from extra-local sources, people and organisations. Social Capital is therefore particularly appealing to policy makers. By building social capital in distressed areas, so the argument goes, employability will improve, employment rates will increase, social ills will decrease, and overall economic development and economic inclusion will occur. Moreover, all this will be done at the grass roots level by the people themselves, with little recourse to (potentially costly) state interventions, which is why it is a seductive proposition for governments.

The above may appear to be a gross simplification of the usefulness of social capital as seen by some of its protagonists, but the issues that are raised must be taken seriously. Can building social capital make such a difference to those excluded and marginalised? This question throws into high relief such potentially attractive benefits of social capital that nearly every government around the world is currently investigating the usefulness of the concept (see PERFORMANCE AND INNOVATION UNIT, 2002; HALPERN 2003, 2004).

But what of the evidence? Empirical investigations do indicate a positive and relatively strong correlation between the strength of social capital and various indicators of employment, economic prosperity and individual well-being. For example, HEENAN (2002) has shown that in relation to the 'New Deal' employment programme in the UK, 
the prospects of a job placement have been substantially enhanced by the systematic use of personal contacts.

It has also been argued that those who have large friendship networks are more likely to find work more easily, and are more likely to be participating in the labour market in the first place (AGUILERA 2002). Seemingly there is also an inverse relationship. KORPI (2001) maintains that there is evidence that a lack of personal and social contacts helps perpetuate long-term unemployment and maintain "ghetto poverty". Recent empirical work by LINDSAY \& MCQUAID (2005) concerning Glasgow's unemployed may confirm this. While PAUGAM \& RUSSELL (2000) maintain that those that are longterm unemployed (the economically excluded) have a declining 'sphere of sociability'.

The theory behind these empirical studies is relatively simple, namely, that the use of personal relations and social networks refracted through prevailing norms of social behaviour, reciprocity and trust increases information flows, reduces transaction costs and lowers the risk associated with economic behaviour; for example, when one is seeking a job. It is posited that social capital produces positive externalities that drive down transaction costs. More generally, PUTNAM (2000), one of leading protagonists of the value of social capital, claims that those societies that are better connected tend to be more prosperous. To summarise, if your stock of social capital is 'high', you are more likely to participate in the labour market and more likely to find a job in the formal sector, or leave worklessness in another manner, i.e. via volunteering and/or employment in the Third Sector.

\section{Context and Caveats}


However, much of the literature which focuses on social capital and economic development highlights a correlation and alleges a causal relationship between social capital and economic development. Many studies undertaken to date fail to demonstrate the causal mechanisms that lead from social capital to economic prosperity and inclusion especially in developed economies (see KELLY \& RAMASWANY, 2002). It is also important to note that whilst the use of social capital might improve the employability of an individual, if the formal economy jobs do not exist in the local area then employment rates are unlikely to increase. On an individual level increased disillusionment is a likely outcome if, having increased employability through developing your stock social capital, jobs still remain unavailable.

Social capital can also be a negative phenomenon, as when elite groups or cliques use it to exclude those not within their circle of connections or when religious affiliations turn to violence as in Northern Ireland. We thus need to specify in what context social capital building is to be deployed before we can determine whether or not it is likely to lead to positive outcomes in terms of economic development. We also need to determine whether social capital building is best undertaken at the level of the individual or the community, and whether by community programmes of by the State

The contextual role of the State is, perhaps, particularly important. TARROW (1996) argues that state structures and actions produce, social capital. LEYS (2001) maintains that social capital has declined everywhere where the state has withdrawn from the provision of important community support and development institutions and functions.

TRIGILIA (2001) believes that public institutions at a non-local level should help "from above" local actors and businesses to mobilise "from below", and produce and use
Formatted: Font: 12 pt, Not Italic, Complex Script Font: 12 pt

Formatted: Font: $12 \mathrm{pt}$, Complex Script Font: $12 \mathrm{pt}$

Deleted: a

Formatted: Font: 12 pt, Complex Script Font: $12 \mathrm{pt}$

Formatted: Font: $12 \mathrm{pt}$, Not Italic, Complex Script Font: 12 pt

Formatted: Font: $12 \mathrm{pt}$, Complex Script Font: 12 pt 


\section{Research Approach}

In order to take into account the context-dependency of the concept and the specificities of the research assignment the authors developed a research framework as shown in Figure 1. The original aim was to provide evidence for a link between increased social capital and employment on an individual level. Community development projects were chosen to be the main focus for this part of the study ${ }^{8}$. We hypothesised a pathway from social capital to employment outcomes loosely based on a neo-weberian analysis which 
maintains that social capital growth is based on both cultural and political contingencies (see TRIGILIA 2001). We considered many customary measures of social capital e.g. volunteering, blood donation, crime rates etc. as consequences, not necessarily direct outcomes (SABATINI 2006) and unsuitable for this study. Instead, we used a range of measures of social capital based on empirical studies from the Australian Family Studies Institute and OECD (STONE et al 2003) which placed emphasis on societal norms of perceptions, feelings of trustworthiness and access to social networks. We proposed that these measures could be expanded to include, increased confidence, well being and optimism, factors which could arguably lead to the development of social skills and personal engagement in society, (FIELD 2003; McQUAID \& LINDSAY 2005).

The research focused on individuals from various communities within the North East, the majority of which were excluded in some way. We maintained that an individual, through community development projects, can improve their confidence and social skills, and increase their social networks and engagement, which can lead to improved attitudes to work, 'employability', and access to employment The next step for the individual would be the actualisation of employment, whether it be in the formal or third sector. Securing employment leads to reduced societal costs, a reduction in the call on the public pursue, in the form of incapacity benefit, and the eventual aggregate economic gain for the region as a whole.

<INSERT FIGURE 1 AFTER HERE >
Formatted: Font: $12 \mathrm{pt}$, Complex Script Font: $12 \mathrm{pt}$

Deleted:

Formatted: Font: $12 \mathrm{pt}$, Complex Script Font: $12 \mathrm{pt}$ 
Figure 1: From social capital to economic prosperity and inclusion

Formatted: Font: $12 \mathrm{pt}$, Bold, Complex Script Font: 12 pt

Formatted: Font: (Default) Times New Roman, 12 pt, Complex Script Font: $12 \mathrm{pt}$

Deleted: <sp>I

II 
In Figure 2 we illustrate how the pathway from social capital building to improved employability, and economic inclusion can be further conceptualised, illustrating the roles of institutions and the types of social capital to be built. [ $\left.{ }^{9}\right]$. We posit that community development projects will build confidence and will lead to the strengthening of 'bonding' $\left[{ }^{10}\right]$ social capital as project participants increasingly feel part of their immediate social group. The outcomes for project participants of this process is the generation of personal contacts and social networks that generate shared understandings, trust and reciprocity within their own social groups. The whole process involves overcoming the 'me -them-and-us' division, namely building 'bridging' [ $\left.{ }^{11}\right]$ social capital; building personal contacts and engaging in social networks between their social groups.

Figure 2: 'Me- Them \& Us' Diagram

Formatted: Font: $12 \mathrm{pt}$, Complex Script Font: $12 \mathrm{pt}$

<INSERT FIGURE 2 AFTER HERE>

Furthermore, project participants using these networks and building increased confidence are more likely to seize the opportunity to construct 'linking' $\left[{ }^{12}\right]$ social capital with job search or educational institutions, which in turn, can lead to increased Formatted: Font: $12 \mathrm{pt}$, Complex Script Font: $12 \mathrm{pt}$ employability. Subsequently, individuals should be able to 'link' with formal sector employment, self-employment, or third sector employment. Increased employability and employment rates will lead to individual and aggregate economic gain, prosperity and economic inclusion. These beneficial outcome, however, are dependent on the contingent circumstances of the prevailing labour market and local economy, and on 
individual pathologies.

An important aim of the study was to assess the impact of social capital building on the employability and economic inclusion of a project participant by delving deeper into the way in which individuals benefit from the opportunities arising from participation in community development projects. Based on this assessment policy recommendations, primarily for ONE, were offered. These recommendations concern the way in which social capital can be built which would significantly improve the employability of those participating in community development projects in the North East.

\section{Case Studies: the impact of building social capital on exclusion}

The results presented in this paper are based on a small-scale in-depth assessment of five community development projects in the North East of England $\left[{ }^{13}\right]\left[{ }_{-1}^{14}\right]$. All projects were located in economically distressed localities, which are characterised by low levels of educational participation and employment. The projects were Community Campus 87, Middlesbrough; (a social enterprise, which houses young homeless people and provides job training); South Tyneside District Hospital, NHS social \& healthcare trainees (a project designed to utilise the skills of disadvantaged members of the local community in the health and social care sector of the region); Houghall Enterprises, Durham (a government project designed to assist those deemed to be disadvantaged start a rural business); SureStart Peterlee (a government SureStart programme providing services to 0-4 year olds and their parents); and Owten Fen Community Association, Hartlepool (a grass roots project with a wide remit of volunteer work, community capacity building and support for local enterprise).

Each project aimed to improve the confidence, well being and 'employability' of their

Deleted: England[
Formatted: Font: $12 \mathrm{pt}$, Complex
Script Font: $12 \mathrm{pt}$
Deleted: ][
Formatted: Font: $12 \mathrm{pt}$, Complex
Script Font: $12 \mathrm{pt}$

Script Font: $12 \mathrm{pt}$
Formatted: Font: $12 \mathrm{pt}$, Complex Script Font: $12 \mathrm{pt}$ 
participants. Project participants $\left[{ }^{15}\right]$, project managers and project stakeholders completed in a semi-structured questionnaire during a face-to-face interview. We summarised the nature of the social capital built within each project, and examined whether project participation did increased the 'employability' of participants.

An attempt was made to quantify the benefits of building social capital for participants, e.g. levers of confidence; well being and optimism, which, in our hypothesised pathway could lead to heightened motivation, increased social contacts or networks and an improved ability to find and retain employment $\left[{ }^{16}\right]$. Participants were asked to rate how they felt 'before' and 'after' participating in the projects, (after a Likert scale of 1-5, 1= most negative, $5=$ most positive); (see Table 1$)$. All participants revealed an increase in their confidence, well being and optimism about the future since joining in project. In most cases the mean score almost doubled. The number and quality of social networks acquired by project participants was also investigated. Participants were asked to rate or quantify their social circle, i.e. immediate family and friends etc. The hypothesis being that by improving your social network will improve your chances of finding work. Participants' progress since joining the project was examined by asking 'before' and 'after' questions (see Table 2 and 3). There was a marked improvement in the level of social contact participants, with the mean score almost doubling after joining the project.
Deleted: , i.e Formatted: Font: 12 pt, Complex Script Font: $12 \mathrm{pt}$ 


\section{Interpretation of the results}

The results of the quantitative and qualitative information gathered, albeit on a small but intensive scale, indicate that participation in the five case study community development projects did improve the confidence, well-being and the social networks of the project participants and, thereby, as in our hypothesised pathway, helped them to increase their social capital. Furthermore, participation in the projects did seem to improve the employability of many of those who participated (indicated by, for example, work experience gained through voluntary work and/or training courses utilised by project participants). However, the evidence indicates that community development projects which build social capital can assist only some people into employment (our research indicated approximately $17 \%$ of respondents directly linked their current employment status to their participation in the community development 
project's linking and networking). If a more palpable link is sought a further longitudinal study must be recommended.

Whether an employment outcome is achieved depends on a range of contingent and contextual factors including, inter alia; (a) the nature of local labour market [are formal sector waged jobs available?], (b) the effectiveness of support systems enabling selfemployment or involvement in the social economy [if jobs in the formal sector just do not exist what are the alternatives in, for example, the third sector?], (c) the nature of the social capital built and characteristics of the individuals participating in the community development projects, and (d) the underlying and distinctive characteristics and pathologies of these individuals. In summary, employment outcomes are dependant on the locational context where social capital is being built.

Context is important. The dislocating effects of the history of the North East of England should not be under-estimated. The collapse of the 'old' industrial economy of coal mining, shipbuilding and heavy manufacturing, led to the destruction of a way of life, and an ordering principle by which people lived and worked. Fragmented, dislocated and isolated communities characterised too many areas of the North East. These communities were (and some remain) characterised by paternalism, authoritarianism, a wage economy mentality, high unemployment and, perhaps what might be described as the wrong sort of strong 'bonding' social capital. This cultural milieu does not lend itself to social inventiveness, adaptability and risk taking entrepreneurialism as seen in more prosperous regions.

We also must be aware that improved employability does not automatically lead to increased employment (economic inclusion); indeed sometimes a 'perverse' (but

Formatted: Font: $12 \mathrm{pt}$, Not Italic, Complex Script Font: $12 \mathrm{pt}$

Formatted: Font: $12 \mathrm{pt}$, Complex Script Font: $12 \mathrm{pt}$ 
understandable) outcome arose in which project participants preferred to stay within the safe confines of the community development project by continuing with voluntary and un-waged work rather than seek waged work beyond the project in the possibly unknown, unsecure and stressful environment of the formal labour market (let alone attempt self employment). It seems confidence was improved only so much for some individuals.

Without having to make reference to the direct and considerable contribution to the economy of the North East made by the voluntary and community sectors $\left[{ }^{17}\right]$ it is clear that the community based development projects reviewed by this research study have made an important contribution to the process of economic inclusion of distressed communities. The outcomes of many community development projects, namely, building confidence, and generating a sense of self-worth and well-being (without necessarily leading to the take-up formal training or employment positions), are valid and important outcomes in their own right. These outcomes do underpin stable, socially cohesive and inclusive communities, and could be regarded as a policy target complementary to a more traditional emphasis on employment and job creation.

\section{Policy Implications}

The North East of England's Regional Development agency, ONE NorthEast, claims to be serious about "unlocking the potential of the people of the North East". As such it is recommended that the agency take seriously the potential of community based development programmes which inter alia aim to build social capital. While our study could not provide a robust link, there was enough preliminary evidence to suggest that the social capital created by these programmes can underpin a process of economic Script Font: $12 \mathrm{pt}$ 
inclusion in the region. As TARROW (1996) suggested, the state can play a key role in producing social capital, especially 'good' social capital, therefore policies designed to support economic inclusion via community development projects must be tailored to the specific needs of the communities of the North East as the contextual history and the prevailing development problems characterising the region must be taken into account.

The building of social capital is not novel, it already taking place at the grass roots level and government agencies must be careful not to inadvertently undermine this source of social capital or encourage the creation of social capital with negative consequences. Policy must be enabling or bottom up as suggested by TRIGILIA (2001). What is required is a recognition of the role community development projects current play in delivering more holistic regeneration agendas (ERRO 1997) and building social capital; government agencies need to design their funding regimes around the projects' current social capital outputs and not prioritise the more traditional quantitative driven outputs of 'number of jobs created' or 'number of people in self employment'.

Furthermore, policy response must be joined up and co-ordinated. Policies designed to promote social capital and those policies designed to encourage the growth of the economy and employment (in the first, second and third sectors) must be integrated. Improving employability through social capital based programmes is unlikely to lead to employment in the formal sector if opportunities are sparse. If this is the case, avenues to non-formal sector activities should be explored, which may entail a different form of social capital to be promoted than that aimed at employability in the formal sector. Furthermore, ADAMS (2005) recently remarked that current Government policy (HMT, ODPM, DTI 2004)- based on a belief that supply side factors (e.g. a lack of education and training) explain regional variations in employment- should be modified 
taking into account that some areas suffer from a marked and continuing lack of labour demand especially in the formal sector. Perhaps then, social capital building should be used to build pathways of employment in both the formal and the informal economy which can still be extremely important in fulfilling basic human needs.

More orthodox economic development policies in distressed areas like the North East, many of which focus on the formal economy, should be complemented with series of measures; some of which will focus on developing social capital and the informal economy. A combination of traditional support programmes (e.g., area based, ILMs, education and training, enterprise development) with social capital building (e.g. promoting community/business co-operatives, support networks, labour and cultural exchanges etc.) is perhaps required. Though, the exact nature of the development possibilities (e.g. an electronics firm or a car plant / a farmers' co-operative or a community recycling activity) will depend on the regional development context and on local contingent circumstances. Specific policy recommendations for the North East could include the following (after HUDSON et al., 2005):

- THE VALUE OF SOCIAL CAPITAL: The strategic significance of social capital should be formally recognised by Government agencies, particularly that which is built through community based programmes and creates pathways to economic inclusion.

- JOINING UP ORGANISATIONS AND ACTIONS: The RDA should, in conjunction with the sub-regional and local strategic partnerships, oversee the coordination of policies, programmes and projects associated with improving employability through community based programmes. 
- SUPPORTING CULTURAL CHANGE: The RDA and its partners should consider ways to accelerate the social interactions between disadvantaged people within the region. Examples to investigate may include schools exchanges; exchanges between youth voluntary groups; community time banks and local economic exchanges. The social capital dimension of public policy and service delivery should also be mainstreamed.

- STRENGTHENING SUB-REGIONAL INVESTMENT PLANS: The RDA its subregional partners should discuss how social capital building for the excluded can be integrated into and prioritised within the sub-regional investment plans. Furthermore, the RDA should discuss with its sub-regional partners and private sector stakeholders how workplace partnerships (focusing on the interaction between community development and corporate social responsibility) can be promoted.

- LEARNING FOR SUCCESS: The RDA and its sub-regional partners should establish a Learning Forum through which experience concerning 'social capital programmes' can be disseminated. What works for whom and under what conditions should be addressed within the Forum. Furthermore, the RDA should formulate an agreed monitoring and evaluation framework for regional social capital programmes and should consider establishing an umbrella regional social capital development strategy.

- ECONOMIC INCLUSION 'PROOFING': Assuming a link between economic inclusion and social capital building the RDA should institute an economic inclusion proofing procedure for economic development programmes. This is an Formatted: Font: $12 \mathrm{pt}$, Not Italic, Complex Script Font: 12 pt inclusion proofing procedure Script Font: $12 \mathrm{pt}$ 
The above recommendations deliberately focus on the actions that the ONE could take in the North East in order to promote the development of social capital and economic inclusion in the region. However there is a more fundamental task in continuing and strengthening the process of joining up the actions of all the social and economic development functions of local government, central government and associated agencies and treating economic development more holistically. A recent review of deprivation trends in Scotland found that a bifurcation of policy concerning social exclusion and economic development has lead to a situation where relative deprivation remains static while in England, where policy is relatively more 'joined up', it has been steadily falling (PALMER, et al 2004).

The benefits of joining-up actions in order to achieve economic inclusion was indeed, recognised by the majority of those interviewed as part of this study. It is "all very well" to promote active involvement in the community, help build 'social networks' for the disadvantaged, and deliver training, but if employment was not available "what was the point?". In this regard it may be appropriate to concentrate on those community

Formatted: Font: $12 \mathrm{pt}$, Not Italic Complex Script Font: $12 \mathrm{pt}$

Formatted: Font: $12 \mathrm{pt}$, Complex Script Font: 12 pt
Deleted:

Formatted: Font: $12 \mathrm{pt}$, Not Italic, Complex Script Font: 12 pt

Formatted: Font: $12 \mathrm{pt}$, Complex Script Font: 12 pt

Formatted: Font: 12 pt, Not Italic Complex Script Font: $12 \mathrm{pt}$

Formatted: Font: 12 pt, Complex Script Font: 12 pt 
development programmes that give project participants access to 'real capital'. DE FILIPPIS (2001) gives an excellent example of such a project. He describes how micro-enterprise lending circles can act as focal points for social networks of the disadvantaged to come together and exercise the power to make lending decisions and allow individual members to realise capital from those networks. Perhaps economic inclusion strategy should prioritise those community based programmes that can demonstrate a planned link between social capital building and access to 'hard' economic resources.

Conversely, if we regard tackling economic exclusion to mean improving the economic well being of the non-working population, then the argument posited by HART \& MACFARLANE (1997) requires serious consideration. They stated, that "since neither the public nor private sector can do more to tackle poverty with their current policies, non-working individuals should be allowed to improve their own household economy". They went on to ask, "if this cannot be done by getting a job [or hard capital], how can it be done?" (p15). What they suggested is not too dissimilar to building social capitalthrough volunteering, and collective self help.

It may be that social capital outcomes (namely building, trust, confidence, and perhaps an ability to more effectively manage risks and opportunities as well as social networks), are valid and important outcomes in their own right; even if a direct causal link between developing social capital and jobs/employment cannot be clearly identified. Further investigation is required as it is these outcomes that often underpin stable, socially cohesive and socially inclusive communities, and it is important to consider alternatives to the orthodox view that economic development can only occur 
through job creation, and exclusion can only be ended through employment in the formal economy.

However, a very recent mood change in the UK Government indicates that it may be increasingly difficult to continue ONE's experimental 'holistic' approach and secure funding for community economic development programmes that go beyond the traditional quantifiable, 'number of jobs created/amount of training provided' orientated programmes. This is regrettable, as in order to make a significant impact on economic exclusion in continually distressed areas like the North East we, perhaps, need a critical mass of community based programmes that build social capital and are directly linked to employment or asset creation. In order for this to occur policy makers should re-visit Formatted: Font: $12 \mathrm{pt}$, Not Italic, Complex Script Font: $12 \mathrm{pt}$

the rigorous defined but somewhat orthodox targets set for the RDAs by DTI 'auditors'. Until this happens, many RDAs may find it difficult to embrace and encourage more holistic economic development practices and programmes needed to tackle persistent social and economic regional disparities. . As TRIGILIA (2001) states: "even more than in the past, economic development has social dimension that cannot be ignored" in our ever increasingly globalised regional economies. 
1

2

3

4

5

6

7

8

9

10

11

12

13

14

15

16

17

18

19

20

21

22

23

24

25

26

27

28

29

30

31

32

33

34

35

36

\section{Acknowledgements}

Thanks go to Professors Ray Hudson and Fred Robinson, University of Durham, $\mathrm{Mr}$ Mike Lazzari of OneNorthEast and to the anonymous references of the draft of the paper who offer insight and constructive comment The views expressed are those of the authors and do not represent those of ONE or any third party. The usual disclaimers apply

\section{References}

ADAMS J (2005) A Full Employment Region. ippr, north, Newcastle, UK.

AGUILERA M (2002) 'The Impact of Social Capital on Labour Force Participation: evidence from the 2000 Social Capital Benchmark Survey', Social Science Quarterly, $83,3,853-874$.

CASEY T. (2004) Social Capital and Regional Economies in Britain. Political Studies $54,96-117$

DE FILIPPIS J (2001) The Myth of Social Capital in Community Development, Housing Policy Debate, $12,4,781-806$

ERRO M (ed.) (1997) Community economic development: linking the grassroots to regional economic development : proceedings of the Regional Studies Association annual conference 1997. Regional Studies Association, London

FIELD J (2003) Social Capital, Routledge, London

FINE B (2001) Social capital versus social theory, Routledge, London

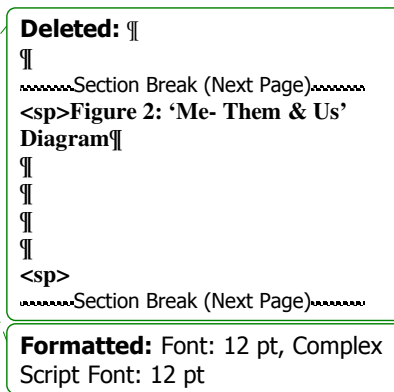

Formatted: Font: 12 pt, Complex Script Font: $12 \mathrm{pt}$

\begin{tabular}{|l|}
\hline Deleted: \\
\hline Deleted: Vol \\
\hline Formatted: Font: $12 \mathrm{pt}$, Not Italic, \\
Complex Script Font: $12 \mathrm{pt}$ \\
\hline Formatted: Font: $12 \mathrm{pt}$, Complex \\
Script Font: $12 \mathrm{pt}$ \\
\hline Formatted: Font: $12 \mathrm{pt}$, Complex \\
Script Font: $12 \mathrm{pt}$ \\
\hline Formatted: Font: $12 \mathrm{pt}$ Italic, \\
Complex Script Font: $12 \mathrm{pt}$ \\
\hline Deleted: . \\
\hline Deleted: Vol \\
\hline
\end{tabular}

Deleted: London 
GROOTAERT C. (1998) Social Capital: the missing link? World Bank. SCI Working Paper No 3 Downloaded: www.worldbank.org/poverty/scapital/wkrppr/wrkppr.htm

HALPERN D (2003) Social Capital and Social Software. Presentation to the Prime Minister's Strategy Unit, $29^{\text {th }}$ May, London, accessed at: http://theworkfoundation.co.uk/pdf/david halpern.pdf, $31^{\text {st }}$ January 2006 y

HALPERN D. (2004) Social Capital, Polity Press, Cambridge

HARRISS J (2003) “Is there value in social capital?” paper presented at the Workshop "Social Capital in the Balkans: The Missing Link?" Jan 31-Feb 1. University of Babes/Bolyai, Cluj-Napoca, Romania

HART M and MACFARLANE R (1997) The Role of Community Enterprise in Local Economic Development: beyond the Job creation agenda?, in ERRO M (ed.) (1997) Community economic development : linking the grassroots to regional economic development : proceedings of the Regional Studies Association annual conference 1997. Regional Studies Association, London

HEENAN D (2002) 'It Won't Change the World But it Turned my Life Around': participants' views on the Personal Advisor Scheme in the New Deal for Disabled People, Disability and Society, 17, 4, 383-401

HMT/ODPM/DTI (HM Treasury, Office of the Deputy Prime Minister, Department for Trade and Industry) (2004). Devolved decision making:2- Meeting the regional economic challenge: Increasing regional and local flexibility HMSO, London

HUDSON R (1989) Wrecking a Region: State Policies, Party Politics and Regional Change in North East England, Pion, London
Deleted: ,

Deleted: d

Formatted: Font: $12 \mathrm{pt}$, Underline, Complex Script Font: $12 \mathrm{pt}$

Formatted: Font: $12 \mathrm{pt}$, Complex Script Font: 12 pt

Formatted: Default Paragraph Font, Font: 12 pt, Underline, Complex Script Font: $12 \mathrm{pt}$

Formatted: Font: $12 \mathrm{pt}$, Complex Script Font: $12 \mathrm{pt}$

Deleted: ,

Formatted: Default Paragraph Font, Font: 12 pt, Complex Script Font: 12 pt

Formatted: Font: 12 pt, Complex Script Font: $12 \mathrm{pt}$

Deleted: , Jan 31-Feb 1.
Deleted: Vol

Deleted: No4 
HUDSON R (2005) Rethinking change in old industrial regions: reflecting on the experiences on North East England, Environment and Planning A, 37,581-596

HUDSON R, MILES N and TULLY, J (2005) Social Capital and Economic Development in the North East of England: promoting economic inclusion through community based programmes and projects. Report for One North East Regional Development Agency, by Durham University, Miles Strategic Consulting and White Young Green: Durham, UK. Accessible at: www.onenortheast.co.uk/reportsandpublications.

KELLY T and RAMASWANY S (2002) (eds.) Social Capital and Economic Development: Well-Being in Developing Countries: Edward Elgar, Northampton, MA

KORPI T (2001). "Good Friends in Bad Times: Social Networks and Job Search among Unemployed in Sweden", Acta Sociologica, 44, 157- 170

LEYS C (2001) Market-driven politics: Neo-liberal democracy and the public interest, Verso: London.

LINDSAY C and MCQUAID R W (2005) Social Capital, Job seeking and long-term unemployment: evidence from research with job seekers in Glasgow. Paper presentation to Regional Studies Association International Conference, University of Aalborg, Denmark, $28^{\text {th }}-31^{\text {st }}$ May, 2005.

MCQUAID R W and LINDSAY C (2005) The concept of employability, Urban Studies, 42 ₹2, 197-219

OXLEY H (1999) Income Dynamics: Inter-Generational Evidence, in Centre for Analysis of Social Exclusion (ed) Persistent Poverty and Lifetime Inequality: The
Formatted: Char, Font: $12 \mathrm{pt}$ Underline, Complex Script Font: 12 pt Formatted: Font: $12 \mathrm{pt}$, Underline, Complex Script Font: $12 \mathrm{pt}$

Formatted: Font: $12 \mathrm{pt}$, Complex Script Font: 12 pt 
Evidence, CASE Report 5 London School of Economics and Political Science, London:

PERFORMANCE AND INNOVATION UNIT of the Cabinet Office (2002) Social

Capital: a discussion paper; Cabinet Office, London

PALMER G, CARR J and KENWAY P (2004) Monitoring Poverty and Social Deleted: York, Inclusion in Scotland 2004, Joseph Rowntree Foundation, York.

PAUGAM S and RUSSELL H (2000). The effects of employment precarity and unemployment on social isolation. In: GALLIE D, PAUGAM S, eds. Welfare regimes and the experience of unemployment in Europe, Oxford University Press, Oxford.

PUTNAM R (2000) Bowling alone: The collapse and revival of American community, Simon and Schuster, New York.

ROSENFIELD S (2002) Just clusters: economic development strategies that reach more people and place. Policy Document, Regional Technology Strategies INC., North Carolina downloaded at: http://www.rtsinc.org/publications.html

Formatted: Font: $12 \mathrm{pt}$, Underline Complex Script Font: $12 \mathrm{pt}$

Formatted: Font: $12 \mathrm{pt}$, Complex Script Font: $12 \mathrm{pt}$

SABATINI F (2006) The Empirics of Social Capital and Economic Development: A Critical Perspective, Working Paper of Fondazione Eni Enrico Mattei, Milan, downloaded at: http://www.feem.it/Feem/Pub/Publications/WPapers/defaulthth, January $31^{\text {st }}, 2006$

Formatted: Default Paragraph Font Font: 12 pt, Underline, Complex Script Font: $12 \mathrm{pt}$

Formatted: Font: $12 \mathrm{pt}$, Complex Script Font: 12 pt

STONE W, GRAY M and HUGHES J (2003) Social capital at work: How family, friends and civic ties relate to labour market outcomes, Research Paper no.31, Australian Institute of Family Studies, Melbourne

TARROW S (1996) Making Social Science work across time and space: A critical Formatted: Font: 12 pt, Italic, Complex Script Font: 12 pt reflection on Robert Putnam's "Making Democracy Work", American Political Science 
Review, 902, 389-97.

TRIGILIA C (2001) Social_Capital_and Local Development. European Journal of

Deleted: Social Theory, 4, 427-442.

WOOLCOCK M (2001) The Place of Social Capital in Understanding Social and Economic Outcomes, Canadian Journal of Policy Research $2 \$ 111-17$

\begin{tabular}{l} 
Deleted: ( \\
Deleted: ) \\
Deleted: : pp \\
\hline
\end{tabular}


Figure 1: From social capital to economic prosperity and inclusion

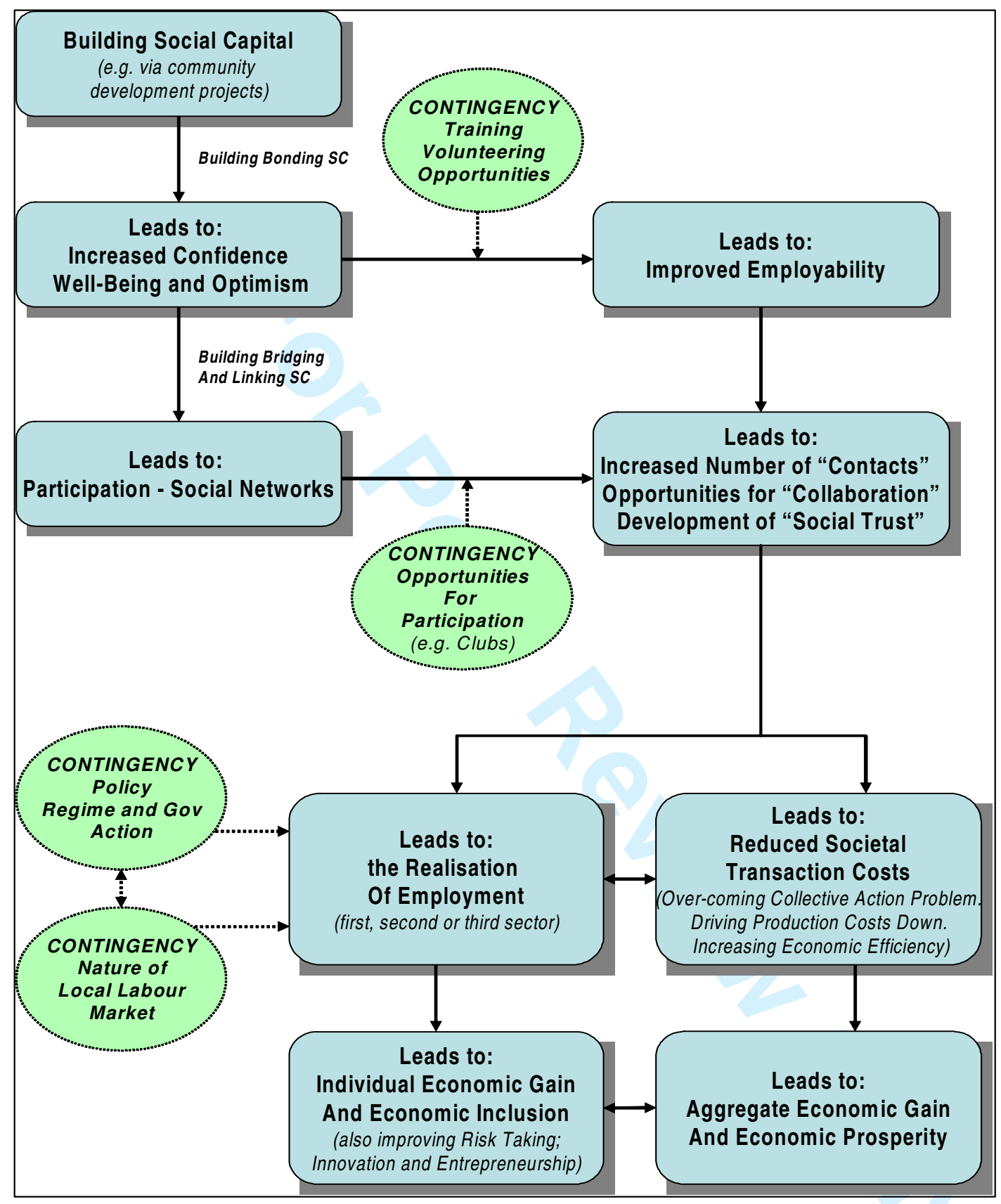




\section{PROMOTING ECONOMIC INCLUSION - Social Capital Formation as a Pathway to Increased Employability}

Context Shaping Social Capital

of the individual
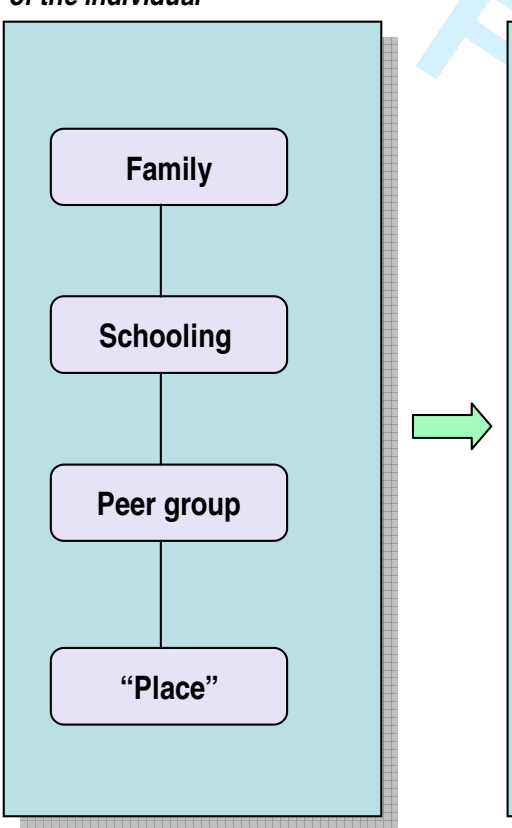

Developi
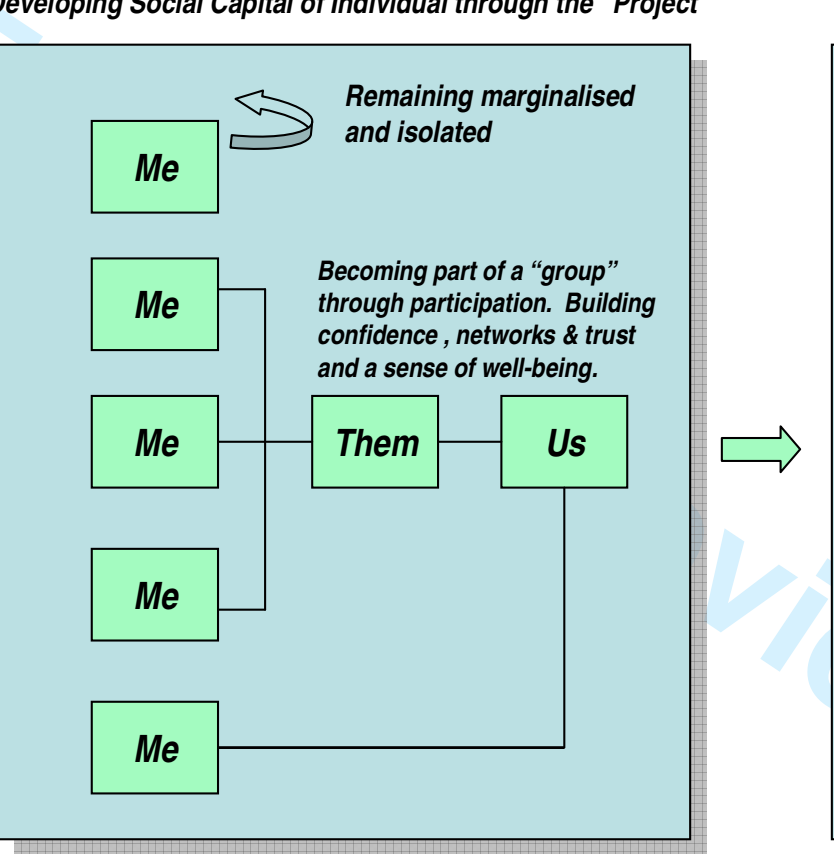

INFORMAL INSTIT. FRAMEWORK - the "context" that defines the type of social

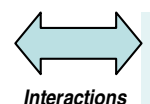
CIVIL SOCIETY INSTITUTIONAL FRAMEWORK Institutions and organisations assisting those "marginalised" participate (and become part of stitutions?

"them") and integrate (and become part of "us"); e.g. Community based / voluntary organisations.
The Individual Using Social Capital

\section{Improved access to a range of resources} (e.g., networks) and opportunities (for employment/ training) 0

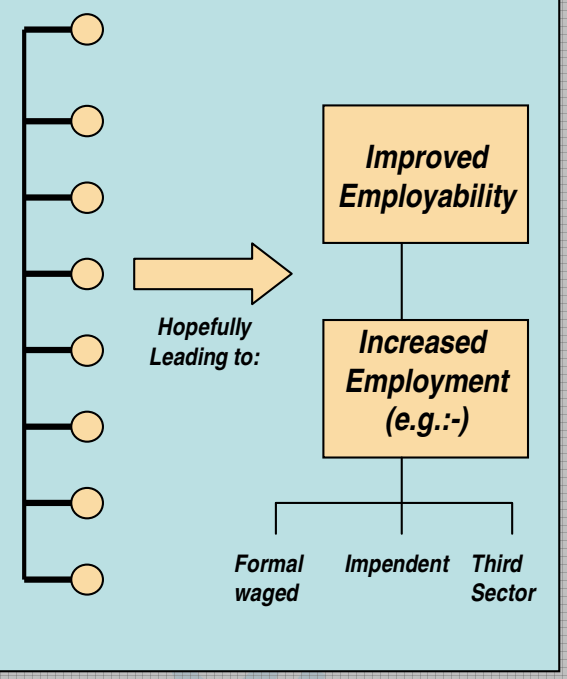

STATE INSTITUTIONAL FRAMEWORK Institutions and organisations assisting target groups find work and/or establish

businesses e.g. Business Links; LSC; Local Authorities; Job Centre Plus.

Different Institutions and different policy levers applicable at different "stages" of the formation and use of social capital "projects" designed to increased employability and employment rates. A key issue of that "joining" up the relevant institutions and policy regimes. 
Table 1: The Effect of Project Participation on Confidence and Well-being (using a 1-5 scale participants were asked to gauge how their feelings about themselves have changed subsequent to joining the project)

\begin{tabular}{|l|c|c|c|c|}
\hline \hline$\underline{\text { What was your....? }}$ & $\underline{\text { Number }}$ & $\underline{\text { score }}$ & $\underline{\text { score }}$ & $\underline{\underline{\text { score }}}$ \\
\hline$\underline{1} \underline{\text { level of confidence BEFORE joining project }}$ & $\underline{23}$ & $\underline{1}$ & $\underline{3}$ & $\underline{2.0}$ \\
$\underline{\text { level of confidence AFTER joining project }}$ & $\underline{23}$ & $\underline{3}$ & $\underline{5}$ & $\underline{4.6}$ \\
\hline$\underline{2} \underline{\text { level of feeling of well being BEFORE joining project }}$ & $\underline{23}$ & $\underline{1}$ & $\underline{4}$ & $\underline{2.3}$ \\
$\underline{\text { level of feeling of well being AFTER joining project }}$ & $\underline{23}$ & $\underline{3}$ & $\underline{5}$ & $\underline{4.4}$ \\
\hline$\underline{3} \underline{\text { level of optimism BEFORE joining project }}$ & $\underline{23}$ & $\underline{1}$ & $\underline{3}$ & $\underline{2.0}$ \\
$\underline{\text { level of optimism AFTER joining project }}$ & $\underline{23}$ & $\underline{3}$ & $\underline{5}$ & $\underline{4.4}$ \\
\hline
\end{tabular}

Table 2: Level of Social Contacts

\begin{tabular}{|l|c|c|c|c|}
\hline What was your....? & $\underline{\text { Number }}$ & $\underline{\text { score }}$ & $\underline{\text { score }}$ & Mean score \\
\hline$\underline{\text { level of social contact BEFORE joining project }}$ & $\underline{23}$ & $\underline{1}$ & $\underline{4}$ & $\underline{2.5}$ \\
level of social contact AFTER joining project & $\underline{23}$ & $\underline{3}$ & $\underline{5}$ & $\underline{4.4}$ \\
\hline
\end{tabular}

Table 3: The Number of Social Contacts

\begin{tabular}{|l|c|c|}
\hline \multicolumn{2}{|l|}{ Is this more, less or the same you had before joining the project? } \\
\hline & Frequency & $\underline{\text { Percent }}$ \\
\hline more & $\underline{13}$ & $\underline{72.2}$ \\
\hline less & 1 & $\underline{5.6}$ \\
same & $\underline{4}$ & $\underline{22.2}$ \\
\hline$\underline{\text { Total }}$ & $\underline{18}$ & $\underline{100.0}$ \\
\hline
\end{tabular}


Table 4: Developing social capital? A summary of Community Development

\section{Projects interviews}

A. Community Campus 87- provides not only a home but a support network or 'family' and as well as employment training for homeless youngsters:

"The key for us is to build confidence and provide a social network for young people- a peer group where they can build friendships in a safe environment....... its about linking people with a shared interest and getting them to socialise... its very important for them to have these networks of support. We see the project as a ladder of participation, getting them to take little steps and getting them used to formal training or even just the idea of formal training" (Project Manager of Community Campus 87) "Without Community Campus, I wouldn't have my house, my job, my life really. If my accommodation hadn't been sorted as well as my emotional stuff, I would have been too $\underline{\text { stressed out to look for work" (Tenant previously homeless, aged 19) }}$

B. NHS social \& healthcare trainees- encourages the development of networks between their employees and local community and networks between local youth and older generations, as well as providing employment training. One of the barriers to employment it tackles, is 'low confidence'.

"In my job I mix with people that I wouldn't have dreamed of speaking to before....like $\underline{\text { the pensioners" (Trainee participant from local area, aged 19) }}$

One of the biggest barriers to employment is low confidence, many people think they're just not worthy of a job, in the NHS or elsewhere......also it doesn't help that the internal job market in the NHS prevents many jobs going to local people... you only get to hear about jobs in the local hospital if you are already employed by the local hospital, therefore 
$\underline{\text { C. Houghall Enterprises- brings together those who are isolated, creating a support }}$ network and helping to realising self- employment ambitions. Having this support group has increased confidence of many individuals.

"Being persuaded to do a presentation to the group in a supportive comfortable setting, increased my confidence. It has enabled me to then develop networking skills which have $\underline{\text { subsequently been essential in making business contacts and winning contracts for my }}$ business" (Project participant, female entrepreneur from rural Durham)

D. SureStart Peterlee- draws isolated young mothers and children into wider social networks, and education and employment training."

"We get people involved first..... get them socialising, talking to other mothers from other areas making them realise they are not on their own, and then get them doing other things like qualifications or training for jobs" (Sure Start Project Worker) "Just about any training course, anything they do, raises their self-confidence and selfesteem and that is reflected in the children"' (Sure Start Project worker) 
${ }^{1}$ This article is based on work undertaken during the summer of 2004 for and funded by ONE NorthEast the Regional Development Agency for the North East of England.

${ }^{2}$ Dr Nicholas Miles is the founding Director of Miles Strategic Consulting Ltd and a research fellow at Centre for Cities and Regions, Durham University- njomiles@ blueyonder.co.uk.

3 Janet Tully is a Senior Research Associate in Centre for the Study of Cities and Regions (CSCR) /Geography, Durham University- janet.tully@dur.ac.uk

4 There exists a wider definition of economically excluded beyond just unemployment, sometimes underemployment, and includes those without economic activity or work- it is interchangeable with the term workless (see definition below).

${ }^{5}$ The UK Department of Work and Pensions (DWP) uses a definition of workless defined as 'people of working age who are not in formal employment but who are looking for a job (the unemployed), together with people of working age who are neither formally employed nor looking for formal employment (the economically inactive)...... Being defined as workless does not necessarily mean that individuals are not undertaking forms of unpaid work or activity such as caring for relatives, looking after children and voluntary work.'. DWP (2005) Understanding Workless people and communities, Research Report No. 225

6 Source: HM Treasury (2003) Public Expenditure: Statistical Analysis 2003, HMSO London.

7 We defined Community Development Projects as those activities that seek to sustain a locality or 'community' for the well being and social, cultural and economic benefit of those living there. They can be public or private sector run, but are more likely to exist in the Third Sector. They are often characterised as seeking 'social justice'.

${ }^{8}$ It was assumed that community development projects were more likely to be already building a form of social capital that could be easily measured. The private sector was also studied, and forms part of a larger study see Hudson et al (2005).

${ }^{9}$ The diagram presented in Figure 1 is informed by the work of the New Economic Foundation (2000) "Prove It: measuring the effect of neighbourhood renewal on local people", London.

10 Bonding- involves closed networks and describes strong ties within homogeneous groups- like family members and close friends. 
11 Bridging- involves overlapping networks where a member of one group can access the networks and resources of another group- like different neighbourhoods, networks through the workplace or sports clubs.

12 Linking- relates to the connections between individuals and groups in hierarchical or power-based relationships- like between the excluded or included, the 'have and have nots' or government and community groups.

13 A further eight community development projects in the North East were also consulted and the information so gained informed our understanding as to how community projects could contribute to the development of social capital in the region.

14 There is still opportunity for further study; the sample used in the analysis was relatively limited, and that time and budget constraints precluded a cross-sectional time-bound method of assessment was used and not an anthropological participant-observation approach which is probably the best form of investigation to use when examining the development and effect of personal relationships and social networks that constitute "social capital".

${ }^{15}$ Of the 30 participants that took part in the study $32 \%$ were male and $68 \%$ female. Their collective ages ranged from 15 to 64 with the median age being 29. A further 17 interviews with stakeholders and project managers helped to contextualise the findings.

${ }^{16}$ Of the 30 participants that took part in the study $32 \%$ were male and $68 \%$ female. Their collective ages ranged from 15 to 64 with the median age being 29 .

17 . "...... the voluntary and community sector makes a significant contribution to the North East economy contributing an estimated $3.8 \%$ of regional GDP. This figure is considerably higher than national estimates of the sectors contribution of $0.67 \%$ of Gross Domestic Product..." Research Solutions (2000). The contribution of the Voluntary and Community Sectors to the Economic Life of the North East region. A report to VONNE (Voluntary Organisations' Network North East). 


\begin{tabular}{|l|c|c|c|c|c|}
\hline Page 15: [1] Deleted & Numbe & Minimu & Maximu & Mean \\
\hline What was your.....? & r & m score & m score & score \\
\hline 1 level of confidence BEFORE joining project & 23 & 1 & 3 & 2.0 \\
level of confidence AFTER joining project & 23 & 3 & 5 & 4.6 \\
\hline $\begin{array}{l}\text { level of feeling of well being BEFORE } \\
\text { joining project } \\
\text { level of feeling of well being AFTER joining }\end{array}$ & & 23 & 1 & 4 & 2.3 \\
project & 23 & 3 & 5 & 4.4 \\
\hline 3 level of optimism BEFORE joining project & 23 & 1 & 3 & 2.0 \\
level of optimism AFTER joining project & $\mathbf{2 3}$ & $\mathbf{3}$ & $\mathbf{5}$ & $\mathbf{4 . 4}$ \\
\hline
\end{tabular}

\begin{tabular}{|c|c|c|c|c|}
\hline Page 15: [2] Deleted & IRHAM UNI & & $5 / 17 / 200$ & 06 2:49:00 PM \\
\hline What was your.....? & Number & $\begin{array}{l}\text { Minimu } \\
\text { m score }\end{array}$ & $\begin{array}{c}\text { Maximum } \\
\text { score }\end{array}$ & Mean score \\
\hline $\begin{array}{l}\text { level of social contact BEFORE joining } \\
\text { project } \\
\text { level of social contact AFTER joining } \\
\text { project }\end{array}$ & 23 & 3 & 5 & 4.4 \\
\hline
\end{tabular}

Is this more, less or the same you had before joining the project? 
A. Community Campus 87- provides not only a home but a support network or 'family' and as well as employment training for homeless youngsters:

"The key for us is to build confidence and provide a social network for young people- a peer group where they can build friendships in a safe environment........ its about linking people with a shared interest and getting them to socialise...its very important for them to have these networks of support.................. We see the project as a ladder of participation, getting them to take little steps and getting them used to formal training or even just the idea of formal training” (Project Manager of Community Campus 87)

“Without Community Campus, I wouldn't have my house, my job, my life really. If my accommodation hadn't been sorted as well as my emotional stuff, I would have been too stressed out to look for work" (Tenant previously homeless, aged 19) 
B. NHS social \& healthcare trainees- encourages the development of networks between their employees and local community and networks between local youth and older generations, as well as providing employment training. One of the barriers to employment it tackles, is 'low confidence'.

“In my job I mix with people that I wouldn't have dreamed of speaking to before....like the pensioners" (Trainee participant from local area, aged 19) One of the biggest barriers to employment is low confidence, many people think they're just not worthy of a job, in the NHS or elsewhere...... also it doesn't help that the internal job market in the NHS prevents many jobs going to local people... you only get to hear about jobs in the local hospital if you are already employed by the local hospital, therefore it helps to know someone on the inside " (Project Stakeholder in South Tyneside)

C. Houghall Enterprises- brings together those who are isolated, creating a support network and helping to realising self- employment ambitions. Having this support group has increased confidence of many individuals.

"Being persuaded to do a presentation to the group in a supportive comfortable setting, increased my confidence. It has enabled me to then develop networking skills which have subsequently been essential in making business contacts and winning contracts for my business" (Project participant, female entrepreneur from rural Durham)

D. SureStart Peterlee- draws isolated young mothers and children into wider 
social networks, and education and employment training."

"We get people involved first..... get them socialising, talking to other mothers from other areas making them realise they are not on their own, and then get them doing other things like qualifications or training for jobs" (Sure Start Project Worker)

“Just about any training course, anything they do, raises their self-confidence and self-esteem and that is reflected in the children"' (Sure Start Project worker)

E. Owten Fens Community Association- networks people in the local community with Central Government and the European Union funding through employment, training or self employment opportunities. A recent networking event where experiences in self employment training 'was successful in raising confidence. "The project has made a great difference... I was on the scrap heap ... .we're given the 112 pounds a month extra so we don't show on the dole statistics .... I would have been stuck in front of the TV at home... Meeting people is important ....it means a lot to me...” (Project participant, aged 57, unemployed for 5 years, working as a volunteer with OFCA) 